\title{
THERMIONIC SYSTEM EVALUATION TEST (TSET) FACILITY CONSTRUCTION: A UNITED STATES AND RUSSIAN EFFORT *
}

\author{
Scott $\mathrm{K}$ Wold \\ Sandia National Laboratories \\ Department 6474 \\ P.O. Box 5800 \\ Albuquerque, NM 87185-5800
}

(505) 272-7241
Conf- $930103-26$
SAND-92-2276C

DE93 004499

\section{Abstract}

The Thermionic System Evaluation Test (TSET) is a ground test of an unfueled Russian TOPAZ-II in-core thermionic space reactor powered by electric heaters. The facility that will be used for testing of the TOPAZ-II systems is located at the New Mexico Engineering Research Institute (NMERI) complex in Albuquerque, NM. The reassembly of the Russian test equipment is the responsibility of International Scientific Products (ISP), a San Jose, CA, company and Inertek. a Russian corporation, with support provided by engineers and technicians from Phillips Laboratory (PL), Sandia National Laboratories (SNL), Los Alamos National Laboratory (LANL), and the University of New Mexico (UNM). This test is the first test to be performed under the New Mexico Strategic Alliance agreement. This alliance consists of the PL, SNL, LANL, and UNM. The testing is being funded by the Strategic Defense Initiative Organization (SDIO) with the PL responsible for project execution.
\end{abstract}

\section{INTRODUCTION}

The Thermionic System Evaluation Test (TSET) facility at the New Mexico Engineering Research Institute (NMERI) complex was prepared for arrival of Russian hardware in less than one year with minimal cost (Fairchild et al. 1992). Numerous building structural changes were made in order to accommodate the Russian TOPAZ-II test hardware. The major changes to the facility were the construction of a 9.1 tonne overhead crane and a $5.49 \mathrm{~m}$ $\times 8.53 \mathrm{~m} \times 4.57 \mathrm{~m}$ deep pit to allow installation of the $5.79 \mathrm{~m}$ tall vacuum chamber. Other changes include installation of an Uninteruptable Power Supply (UPS) consisting of motor and diesel generators to provide 380 VAC, $50 \mathrm{~Hz}$ power required by the Russian equipment, and a three-level test stand to support the TOPAZ-II vacuum chamber in the pit.

The cost of preparation of the support facility was held to a minimum value by using on-site engineers and technicians to complete as much of the fabrication and installation of equipment as possible. Equipment costs were held down by acquiring equipment salvaged from Sandia National Laboratories (SNL) and Los Alamos National Laboratory (LANL) equipment reapplication yards. An estimated 400 thousand dollars (US) was saved by refurbishing this salvaged equipment.

The TSET facility (Figure 1) consists of two work areas ("High Bay" and "Low Bay"), a control room, and a large outdoor courtyard area. The high bay houses TOPAZ-II, its vacuum chamber, a tungsten heater outgassing stand, and miscellaneous support equipment. The low bay contains an electrically heated single-cell thermionic fuel element (TFE) test rig, and an electronic equipment work station. The control room contains the instrumentation and control equipment for operation of the TOPAZ-II and support equipment. The courtyard area contains the UPS equipment, a motor and engine generator, a machine shop. a liquid nitrogen $\left(\mathrm{LN}_{2}\right)$ tank and a pump room that houses the roughing vacuum and cooling water pumps. The major modifications to the TSET facility at the NMERI complex were completed in November 1991.

The TSET UPS system provides a five-minute battery backup to operate the motor generator set if site power is lost. This provides time to bring the engine generator system on line. This backup power system is required to minimize the number of thermal transients to TOPAZ-II, which limit the lifetime of the satellite (Fairchild et al. 1992).

\footnotetext{
* this work was sponsored by SDIO and supported by Sandia National Laboratories, which is operated for the U.S. Department of Energy under contract DE-AC04-76DP00789.
} 


\section{DISCLAIMER}

This report was prepared as an account of work sponsored by an agency of the United States Government. Neither the United States Government nor any agency Thereof, nor any of their employees, makes any warranty, express or implied, or assumes any legal liability or responsibility for the accuracy, completeness, or usefulness of any information, apparatus, product, or process disclosed, or represents that its use would not infringe privately owned rights. Reference herein to any specific commercial product, process, or service by trade name, trademark, manufacturer, or otherwise does not necessarily constitute or imply its endorsement, recommendation, or favoring by the United States Government or any agency thereof. The views and opinions of authors expressed herein do not necessarily state or reflect those of the United States Government or any agency thereof. 


\section{DISCLAIMER}

Portions of this document may be illegible in electronic image products. Images are produced from the best available original document. 


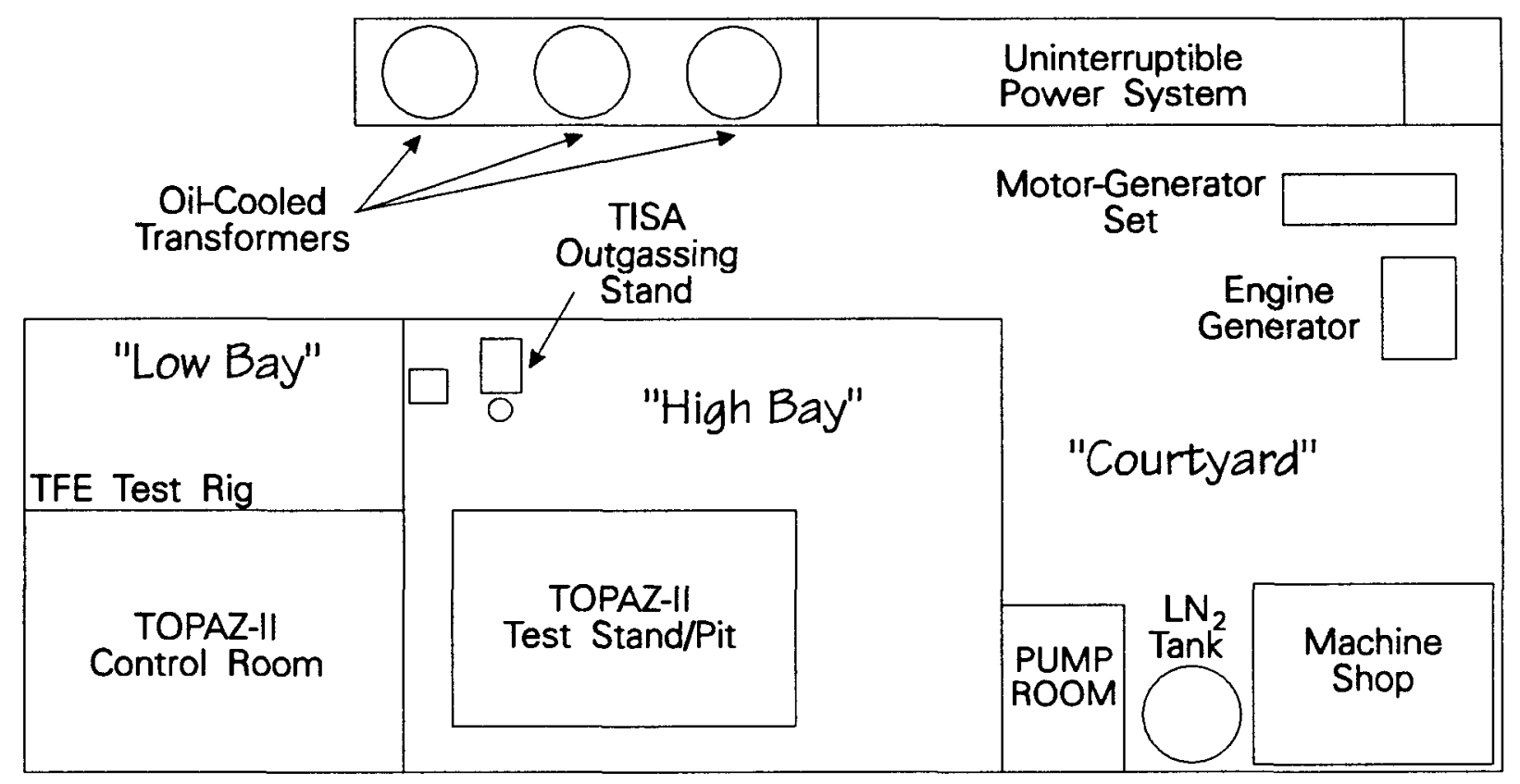

FIGURE 1. TSET Facilities at the NMERI Complex.

\section{TRAINING}

Although the TOPAZ-II contains no nuclear fuel, the training and conduct of operations is similar to those found in the United States (US) commercial and Department of Energy (DOE) nuclear facilities. The training program consists of Subject Matter Experts; personnel who are responsible for tracking and researching a specific system of the facility, who then train all other personnel. This cross-training of personnel results in a higher confidence in the operators, who can operate the complex facility systems through knowledge, rather than using a "cookbook" approach.

The training of personnel began in November 1991, after the completion of a large portion of the facility modifications. Personnel were trained and tested on support and safety systems installed in preparation for the arrival of Russian hardware. Training on the TOPAZ-II NaK cooling and cesium systems was also conducted. Members of the US staff attended training on vacuum systems given by the American Vacuum Society, a short course on Thermionic Energy Conversion presented by Thermo Electron Technologies, Rasor Associates, Space Power Inc., and General Atomics, and a liquid metal safety course by Space Power Inc.

Specific training on the TOPAZ-II and TFE test-stand systems was presented to the US staff by members of the Central Design Bureau of Machine Building (CDBMB) from St. Petersburg, Russia, and the Kurchatov Institute from Moscow, Russia, during a four week period in April 1992. Fourteen Russian engineers, designers, technicians and translators arrived in Albuquerque, NM, to conduct specific training on Russian systems. The training was split into two groups: one for the TSET project and another for flight safety and nuclear studies. The training averaged 40 hours per week for the four week period. During this time, questions that had not been answered through correspondence were answered directly, and the US staff was better prepared for the arrival and installation of the TOPAZ-II hardware.

\section{TSET EQUIPMENT ASSEMBLY}

The reassembly of the TOPAZ-Il support and test equipment was accomplished over a four-month period and is described below. 


\section{Arrival of Russian Hardware}

During the spring of 1992, the United States sent a number of Air Force C-5 transport planes to Russia fully loaded with cargos of food and medicines and the planes would return empty. The TOPAZ-II hardware that was disassembled from the CDBMB facility had been crated and stored in a warehouse in St. Petersburg. Arrangements were made to transport the TOPAZ-II hardware from St. Petersburg to Albuquerque on two of the returning C-5 transport planes. The first transport arrived on 7 May 1992, and the second followed on 12 May 1992.

The crates were unloaded and stored in a hangar at Kirtland Air Force Base in Albuquerque, NM, in a manner that would facilitate easy access. The order of unpacking the Russian crates was determined during the Russian training in April 1992. The crates were transported to the NMERI complex by members of the US TSET staff. The control room equipment and lower level pit equipment was removed from crates and put into place by the US staff before the arrival of 14 Russian engineers and technicians on 3 June 1992.

\section{Installation of Support Equipment}

The Russian engineers and technicians each have their own field of expertise. These include instrumentation and control, electrical distribution, vacuum systems, water cooling, and tungsten heater outgassing. In order to facilitate construction and training, a member of the US staff was assigned to the lead Russian engineer in each of the fields of work. The language barrier was not as difficult as it was thought it would be due to the hard work of the translators and the camaraderie developed between the Russian and US specialists.

Installation of equipment was performed simultaneously on the instrumentation and electrical systems in the control room and on the vacuum and cooling water systems in the pit. A majority of the cable and pipe runs had to be cut and fit into place because of the differences in the TSET and St. Petersburg test facilities. This work was made easier due to the large amount of spare cable and piping that was shipped to Albuquerque as part of the purchase. The US staff fabricated and installed the cable trays, conduit and pipe clamps to support the Russian hardware, then the Russian and US staff would then install the cables and piping. Most of this support work was performed after normal working hours in order to meet the schedule for equipment installation.

\section{TOPAZ-II Inspection}

A TOPAZ-II power system was removed from its shipping container in June 1992. The TOPAZ-II thermionic power system contains beryllium metal components that may have undergone vibration and surface abrasion during transport. The Inhalation Toxicology Research Institute (ITRI) assessed and mitigated the possible beryllium inhalation hazard associated with opening the shipping container and handling the power system. ITRI obtained air and surface samples during the removal of the TOPAZ-II from the shipping container. Real-time beryllium analysis support was provided by LANL. No airborne beryllium was found in the shipping container air. Internal surfaces of the container and external surfaces of the TOPAZ-II reactor support frame were sampled and trace amounts of beryllium were found. These amounts posed no hazard to workers and were reduced by cleaning the surfaces with alcohol wipes and vacuuming. Trace amounts of airborne beryllium were detected during the cleaning process, but the concentrations were well below the US Occupational Safety and Health Act (OSHA) limits for occupational exposure of workers, and were even below US Environmental Protection Agency (EPA) limits for exposure of the general population (Hoover et al. 1992).

\section{Installation of Vacuum Chamber Sections}

The vacuum chamber sections were installed in the test stand in July 1992. This allowed a final mechanical fit of the numerous water, vacuum, and cesium lines. This also allowed the Russian and US engineers to make accurate measurements and design the vacuum chamber support equipment. Russian and US technicians were also able to fabricate and install the required mechanical and electrical support equipment. 
Following this initial fit testing, the upper vacuum chamber sections were removed. The second TOPAZ-II was removed from its shipping container, analyzed for beryllium contamination, and installed in the base of the vacuum chamber. This allowed the installation of the cesium exhaust piping and cooling water jackets located inside the vacuum chamber. Upon completion of this work the TOPAZ-II was returned to its shipping container.

\section{OUTGASSING TISA HEATERS}

The first system to be completely assembled was the TISA heater outgassing rig. The TISA heaters are made of tungsten metal and are used to produce the necessary temperatures required for the thermionic elements. These heaters are installed in the center of the TFEs where the nuclear fuel would be located in a space based system. The use of these heaters and the single-cell thermionic design allows testing of the TOPAZ-II power system prior to nuclear fuel loading.

The TISA heaters must be outgassed before they are installed into the TFEs. This is accomplished by installing the heaters into a small vacuum chamber, lowering the pressure to approximately 5 x E-5 torr, and applying current to the heater. The TISA vacuum chamber can accommodate one heater at a time and the complete outgassing process lasts approximately 20 hours. After outgassing, the TISA heaters are stored in stainless steel canisters that are evacuated and backfilled with argon.

The length of time needed to outgas the heaters required the US and Russian staff to operate the rig 24 hours a day, 7 days a week for 8 weeks. This was accomplished by rotating staff on 12 hour shifts for a 4 day period. This time on shift was used to train the US staff in the operation of the Russian equipment and the use of procedures. The TISA outgassing rig is a small version of the larger vacuum chamber and TOPAZ test equipment and was an excellent tool to train the US staff in preparation for the TOPAZ II tests.

\section{VACUUM CHAMBER PUMP DOWN}

Following installation of the vacuum chamber support equipment, the chamber sections were cleaned and reinstalled on the test stand. The vacuum lines were pumped down and checked for leaks up to the isolation valves for the vacuum chamber. On 14 September 1992, the vacuum chamber was pumped down using the mechanical fore vacuum pumps and at a vacuum of $5 \times$ E-2 torr, two $10,000 \mathrm{~L} / \mathrm{s}$ turbomolecular pumps were started. The vacuum chamber pumped down to $5 \times$ E-5 torr in less than one day with the turbomolecular pumps and was then checked for leaks. The chamber was kept at a vacuum of approximately $5 \times$ E-5 torr in order to outgas the materials inside the chamber. A mass spectroscopy of the products outgassing from the chamber was performed, and the results will be compared to the products outgassed with the satellite in the chamber. The TOPAZ-II power system is currently scheduled for installation into the vacuum chamber in October 1992 and will be followed by acceptance testing.

\section{CONCLUSIONS}

The problems with working with the Russian engineers (due to the language barriers) were not as difficult as originally anticipated. The US and Russian staff members developed a very good working relationship immediately and communication between the engineers and technicians was not difficult. The US staff and many of the Russian staff have some knowledge of the others' language. Basic working communications are carried out by the use of a few key words and numerous drawings and sketches. The remainder of the translations are performed by an outstanding support staff of technical translators at the facility. Reassembly of the CDBMB TOPAZ-II test facility was completed approximately three months ahead of the original schedule despite the language differences. Testing of the Russian hardware will help "jump-start" lagging US thermionic reactor development (Henderson 1991). The facility, following the completion of TOPAZ-II testing, can be used for other types of testing important to the space and reactor communities (Fairchild et al. 1992). 


\section{Acknowledgments}

Funding for this project is being provided by SDIO and is being conducted at the NMERI facility by International Scientific Products (ISP), Inertek, Phillips Laboratory (PL), Sandia National Laboratories (SNL), Los Alamos National Laboratory (LANL), and the University of New Mexico (UNM).. Special thanks to the US and Russian staff members for their professionalism, dedication, and the many long hours of hard work in support of the project.

\section{References}

Fairchild, J.F, J.P. Koonmen, and F.V. Thome (1992) "Thermionic system Evaluation Test (TSET) Facility Description," in Proc. Ninth Symposium on Space Nuclear Power Systems, CONF-920104, M. S. El-Genk and M. D. Hoover. eds., American Institute of Physics, New York.

Henderson, B. W. (1991) "US Buying Soviet TOPAZ 2 to Boost space Nuclear Power Program," Aviation Week and Space Technology, 14 January 1991, pp. 54-55.

Hoover, M. D., G. L. Finch, G. J. Newton, and D. A. Cremers (1992) "Assessment and Mitigation of Beryllium Inhalation Hazards in the TOPAZ II Thermionic Space Nuclear Power System: Air and Surface Measurements June 1992," ITRI-920602, Inhalation Toxicology Research Institute, Albuquerque, NM 